\title{
PERBANDINGAN TEKANAN DARAH ANTARA PENDUDUK YANG TINGGAL DI DATARAN TINGGI DAN DATARAN RENDAH
}

\author{
Inka A. T. Sukarno \\ Sylvia Marunduh \\ J. J. V Rampengan
}

\author{
Bagian Fisiologi Fakultas Kedokteran Universitas Sam Ratulangi Manado \\ Email: meiji12@rocketmail.com
}

\begin{abstract}
Blood pressure is the pressure generated by the blood against the blood vessel. Blood pressure is affected by blood volume and elasticity of blood vessels. Increased blood pressure is caused by an increase in blood volume or blood vessel elasticity. Conversely, a decrease in blood volume will lower blood pressure. The aim of this study was to compare the profile of blood pressure among people living in the highlands and lowlands (coast). This was an analytic survey research methods using 160 samples. The data obtained through the measurement of blood pressure using sphygmomanometers $\mathrm{ABN}$ and Littman stethoscope. Data distribution based on blood pressure classification (WHO criteria) was tested using Chi-Square test. The results showed that the number of people with normal systole and diastole are more in the highlands (75\% and $72.5 \%$ ) than in the lowlands (55 \% and $36.25 \%$ ). There are more respondents with hypertension both systolic and diastolic in the lowlands (45\% and $63.75 \%$ ) than in the highlands (25\% and $27.5 \%$ ). Furthermore, blood pressure measurement data were analyzed using the Mann Whitney U test. Based on tests, there is a significant difference between people living in the higlands and lowlands ( $\alpha<0.05$ ), so that $\mathrm{H} 1$ is accepted and HO is rejected. Conclusions: There is a significant difference in the measurement of blood pressure among people living in the highlands and lowlands.
\end{abstract}

Keywords: blood pressure, highland, lowland (coast)

\begin{abstract}
Abstrak: Tekanan darah adalah tekanan yang dihasilkan oleh darah terhadap pembuluh darah. Tekanan darah dipengaruhi volume darah dan elastisitas pembuluh darah. Peningkatan tekanan darah disebabkan peningkatan volume darah atau elastisitas pembuluh darah. Sebaliknya, penurunan volume darah akan menurunkan tekanan darah. Penelitian ini bertujuan untuk mengetahui perbandingan hasil tekanan darah antara penduduk yang tinggal di dataran tinggi dan dataran rendah. Metode penelitian survey analitik dengan 160 sampel. Data di peroleh melalui pengukuran tekanan darah menggunakan tensimeter ABN dan stetoskop Littman. Distribusi data berdasarkan klasifikasi tekanan darah WHO di uji menggunakan uji Chi-Square. Hasil penelitian menunjukkan bahwa jumlah penduduk dengan tekanan darah normal sistole $75 \%$ dan diastole $72,5 \%$ lebih banyak di dataran tinggi dibandingkan dengan dataran rendah berturut-turut 55\% dan 36,25\%. Lebih banyak ditemukan hipertensi dengan sistole $45 \%$ dan diastole $63,75 \%$ di dataran rendah di bandingkan dengan dataran tinggi masingmasing $25 \%$ dan $27,5 \%$. Selanjutnya, data hasil pengukuran tekanan darah di analisis menggunakan uji Mann Whitney U. Berdasarkan uji statistik di dapatkan ada perbedaan yang signifikan antara penduduk yang tinggal di dataran tinggi dan dataran rendah $(\alpha<0.05)$, sehingga $\mathrm{H} 1$ diterima dan HO ditolak. Simpulan: terdapat perbedaan yang bermakna pada pengukuran tekanan darah antara penduduk yang tinggal di dataran tinggi dan dataran rendah.
\end{abstract}

Kata Kunci: tekanan darah, dataran tinggi, dataran rendah (pesisir pantai) 
Tekanan darah merupakan hal yang sangat penting dalam sistem sirkulasi darah. Tekanan darah selalu diperlukan untuk daya dorong mengalirkan darah di dalam arteri, arteriola, kapiler, venula, dan vena. ${ }^{1}$ Jantung bekerja sebagai pemompa darah dapat memindahkan darah dari pembuluh vena ke pembuluh arteri pada sistem sirkulasi tertutup. ${ }^{1}$ Siklus jantung terdiri atas periode relaksasi yang dinamakan diastole diikuti oleh periode kontraksi yang dinamakan sistole. ${ }^{2}$ Tekanan sistolik adalah tekanan puncak yang ditimbulkan oleh darah yang disemprotkan pada dinding pembuluh selama sistole jantung. Tekanan diastolik adalah tekanan minimum di arteri sewaktu darah mengalir ke luar untuk memasuki pembuluhpembuluh selama diastole jantung. ${ }^{3}$

Terdapat dua macam kelainan tekanan darah, yaitu yang dikenal sebagai hipertensi atau tekanan darah tinggi dan hipotensi atau tekanan darah rendah. ${ }^{3}$

Klasifikasi tekanan darah menurut WHO :

Tabel 1. Klasifikasi tekanan darah menurut WHO adalah sebagai berikut: ${ }^{12}$

\begin{tabular}{lcc}
\hline KATEGORI & SISTOLIK & DIASTOLIK \\
\hline Optimal & $<120$ & $<80$ \\
Normal & $<130$ & $<85$ \\
Normal-Tinggi & $130-139$ & $85-89$ \\
Hipertensi Ringan & $140-159$ & $90-99$ \\
Hipertensi Sedang & $160-179$ & $100-109$ \\
Hipertensi Berat & $>180$ & $>110$ \\
\hline
\end{tabular}

Secara global prevalensi hipertensi pada orang dewasa 25 tahun ke atas adalah sekitar 40\% pada tahun 2008. ${ }^{4}$ Menurut World Health Organization (WHO) prevalensi hipertensi di Indonesia pada tahun 2008 adalah 37,4\%. ${ }^{5}$ Berdasarkan Riset Kesehatan Dasar (Riskesdas) 2007, prevalensi hipertensi di Sulawesi Utara adalah 31,2\%. Prevalensi hipertensi tertinggi di Kepulauan Natuna (pesisir pantai) pantai sebanyak 53,3\%, sedangkan terendah di Pegunungan Jayawijaya sebanyak 6,8\%. ${ }^{6}$ Menurut Bustan, orang yang tinggal di daerah kota lebih banyak ditemukan adanya hipertensi dibandingan dengan orang yang hidup di desa, selain itu letak geografis dimana daerah pantai lebih banyak kejadian hipertensi dari pada daerah pegunungan. ${ }^{9}$ Penelitian yang pernah dilakukan oleh Setiawati S di pesisir pantai Pulau Manado Tua, Manado diperoleh adanya hubungan yang signifikan antara asupan natrium dengan kejadian hipertensi. ${ }^{10}$

Rumusan MasalahBagaimana perbandingan tekanan darah antara penduduk yang tinggal di dataran tinggi dan dataran rendah ?

\section{METODE PENELITIAN}

Penelitian ini bersifat survey analitik dengan rancangan cross sectional study dan dilakukan pada bulan Desember 2013 sampai Januari 2014. Populasi dan sampel ialah penduduk yang tinggal di dataran tinggi Kelurahan Rurukan Kota Tomohon dan dataran rendah Kelurahan Malalayang Kota Manado. Kriteria inklusi antara lain: pria dan wanita yang bertempat tinggal di Kelurahan Rurukan dan Kelurahan Malalayang yang telah berdomisili minimal 5 tahun, usia 18-65 tahun dan bersedia menjadi subyek penelitian dengan menandatangani informend consent. Sebagai variabel penelitian, variabel bebas adalah penduduk yang tinggal di dataran tinggi dan dataran rendah dan variabel tergantung adalah tekanan darah. Alat dan bahan penelitian di pakai stetoskop littman dan tensimeter ABN. 
Definisi operasional tekanan darah adalah tekanan yang mendorong darah sehingga dapat mengalir melalui pembuluh darah. Penduduk adalah orang-orang yang berdomisili secara tetap dalam wilayah suatu daerah untuk jangka waktu yang lama. Dataran tinggi merupakan daerah perbukitan, dimana permukaan atasnya cenderung curam, dengan jarak $>700$ meter dari permukaan laut. Dataran rendah merupakan hamparan luas tanah dengan tingkat ketinggian yang di ukur dari permukaan laut adalah relatif rendah sampai dengan 200 meter.

\section{Prosedur Pelaksanaan Penelitian}

Setiap subyek diminta untuk mengisi surat pernyataan bersedia untuk di teliti. Subyek yang memenuhi kriteria inklusi di minta untuk mengikuti prosedur penelitian dengan terlebih dahulu menjawab kuesioner. Selanjutnya, dilakukan pengukuran tekanan darah kepada subyek dengan menggunakan stetoskop dan tensimeter.

\section{Pengolahan Data}

Analisis Univariat : untuk mendapatkan gambaran tekanan darah pada masing-masing lokasi (dataran tinggi dan rendah) dihitung secara distribusi frekuensi dan disajikan dalam bentuk tabel. Analisis Bivariat : Untuk mengetahui perbadingan klasifikasi tekanan darah menurut WHO 2003 di uji secara statistik dengan uji Chi-Square, nilai $p=0,05 \quad(p>0,05=$ HO dan $\mathrm{p}<0,05=\mathrm{H1}$ ). Untuk mengetahui perbandingan hasil tekanan darah antara penduduk yang tinggal di dataran tinggi dan rendah di uji secara statistik dengan non parametric yaitu uji Mann Whitney U dengan nilai $\alpha=0,05(\alpha>0,05=$ HO dan $\alpha<0,05=\mathrm{H} 1)$.

\section{HASIL PENELITIAN DAN BAHASAN}

\section{Gambaran Umum}

Penelitian ini dilaksanakan di dua tempat yaitu di Kelurahan Rurukan Kota Tomohon dan Kelurahan Malalayang Kota Manado. Kelurahan Rurukan mempunyai ketinggian \pm 939 meter dari permukaan laut, luas Kelurahan total 350 hektar dan luas wilayah pemukiman 12 hektar. Penduduk yang tinggal di Kelurahan ini sekitar 1763 jiwa yang terdiri dari 446 kepala keluarga. Kelurahan Malalayang mempunyai ketinggian 5-10 meter di atas permukaan laut, luas wilayah 1.000 hektar dan populasi 704 jiwa yang terdiri dari 230 kepala keluarga bertempat tinggal dipesisir pantai.

\section{Karakteristik subyek penelitian}

Pada penelitian ini, penduduk yang diteliti berjumlah 160 orang. Penduduk yang bertempat tinggal di Kelurahan Rurukan sebanyak 80 orang dan Kelurahan Malalayang sebanyak 80 orang yang telah berdomisili minimal 5 tahun dan berumur 18-65 tahun. Penduduk yang menjadi sampel penelitian memiliki pekerjaan sebagai petani, nelayan, pegawai negeri sipil (PNS), ibu rumah tangga (IRT), wiraswasta, dan mahasiswa.

\section{Distribusi Hasil Pengukuran Tekanan Darah Penduduk Yang Tinggal Di Dataran Tinggi Dan Dataran Rendah Berdasarkan Jenis Kelamin}


Tabel 2. Distribusi Hasil Pengukuran Tekanan Darah Penduduk yang Tinggal Di Dataran Tinggi dan Dataran Rendah Berdasarkan Jenis Kelamin

\begin{tabular}{ccccccc}
\hline Jenis Kelamin & \multicolumn{2}{c}{$\begin{array}{c}\text { Dataran } \\
\text { Tinggi }\end{array}$} & \multirow{2}{*}{$\begin{array}{c}\text { Rerata TD } \\
(\mathrm{mmHg})\end{array}$} & \multicolumn{2}{c}{$\begin{array}{c}\text { Dataran } \\
\text { Rendah }\end{array}$} & \multirow{2}{*}{$\begin{array}{c}\text { Rerata TD } \\
\text { (mmHg) }\end{array}$} \\
& $\mathrm{n}$ & $\%$ & & $\mathrm{n}$ & $\%$ & \\
\hline Laki-laki & 34 & 42,5 & $121 / 77$ & 51 & 63,75 & $138 / 91$ \\
Perempuan & 46 & 57,5 & $130 / 81$ & 29 & 36,25 & $134 / 87$ \\
\hline Total & 80 & 100 & & 80 & 100 & \\
\hline
\end{tabular}

Berdasarkan tabel 2, yang menjadi subjek penelitian pada penelitian di dataran tinggi paling banyak adalah perempuan yang berjumlah 46 orang $(57,5 \%)$ daripada laki-laki yang berjumlah 34 orang $(42,5 \%)$ dan di dataran rendah paling banyak adalah laki-laki yang berjumlah 51 orang $(63,75 \%)$ daripada perempuan yang berjumlah 29 orang (36,25\%).

Hasil penelitian pengukuran tekanan darah berdasarkan jenis kelamin tidak terdapat perbedaan yang siginifikan pada laki-laki dan perempuan. Hasil penelitian ini sesuai dengan penelitian yang dilakukan oleh Sugihartono A bahwa jenis kelamin perempuan tidak terbukti sebagai faktor hipertensi. ${ }^{14}$ Ahli lain mengatakan pria dan wanita menopause mempunyai pengaruh yang sama untuk terjadinya hipertensi. ${ }^{15}$

\section{Distribusi Penduduk Menurut Umur}

Tabel 3. Distribusi Penduduk Menurut Umur

\begin{tabular}{ccccc}
\hline \multirow{2}{*}{ Umur } & \multicolumn{2}{c}{ Dataran Tinggi } & \multicolumn{2}{c}{ Dataran Rendah } \\
& $\mathrm{n}$ & $\%$ & $\mathrm{n}$ & $\%$ \\
\hline $18-35$ & 13 & 16,25 & 22 & 27,5 \\
$36-45$ & 30 & 37,5 & 21 & 26,25 \\
$46-55$ & 28 & 35 & 24 & 30 \\
$56-65$ & 9 & 11,25 & 13 & 16,35 \\
\hline Total & 80 & 100 & 80 & 100 \\
\hline
\end{tabular}

Berdasarkan tabel 3, kelompok umur penduduk di dataran tinggi paling banyak umur 3645 tahun sebanyak 30 orang (37,5\%) dan di dataran rendah paling banyak umur 46-55 tahun sebanyak 24 orang (30\%). Semakin meningkat umur seseorang maka akan berpengaruh pada peningkatan tekanan darah. Bertambahnya umur menyebabkan hilangnya elastisitas pembuluh darah yang berdampak pada daya arteri dan aorta dalam sirkulasi aliran darah. ${ }^{7}$ Hal ini sejalan dengan penelitian yang dilakukan oleh Sundari, dkk di wilayah pantai bahwa faktor umur berpengaruh pada hipertensi. ${ }^{12}$

\section{Distribusi Penduduk Menurut Pekerjaan}


Tabel 4. Distribusi Penduduk Menurut Pekerjaan

\begin{tabular}{lcccc}
\hline \multirow{1}{*}{ Pekerjaan } & \multicolumn{2}{c}{ Dataran Tinggi } & \multicolumn{2}{c}{ Dataran Rendah } \\
& $\mathrm{n}$ & $\%$ & $\mathrm{n}$ & $\%$ \\
\hline PNS & 7 & 8,75 & 1 & 1,25 \\
Wiraswasta & 11 & 13,75 & 14 & 17,5 \\
IRT & 18 & 22,5 & 27 & 33,75 \\
Mahasiswa & 0 & 0 & 1 & 1,25 \\
Petani & 40 & 50 & 2 & 2,5 \\
Nelayan & 0 & 0 & 18 & 22,5 \\
Buruh & 0 & 0 & 6 & 7,5 \\
Pensiunan & 0 & 0 & 1 & 1,25 \\
dll & 4 & 5 & 10 & 12,5 \\
\hline Total & 80 & 100 & 80 & 100 \\
\hline
\end{tabular}

Berdasarkan tabel 4, pekerjaan penduduk di dataran tinggi yang ikut serta dalam penelitian ini terbanyak adalah bekerja sebagai petani berjumlah 40 orang (50\%) dan paling sedikit adalah tidak bekerja (dll) sebanyak 4 orang (5\%). Pekerjaan penduduk yang tinggal di dataran rendah terbanyak adalah bekerja sebagai IRT sebanyak 27 orang (33,75\%) dan paling sedikit bekerja sebagai PNS, pensiunan serta mahasiswa masing-masing sebanyak 1 orang (1\%).

Berdasarkan referensi di atas. pekerjaan penduduk yang tinggal di dataran rendah paling banyak adalah sebagai ibu rumah tangga. Setiawati pada penelitiannya terhadap kasus hipertensi di Pulau Manado Tua paling banyak pada ibu rumah tangga. Hal ini di sebabkan oleh karena ibu rumah tangga hanya tinggal di rumah dan kurang beraktifitas. ${ }^{10}$

\section{Distribusi Penduduk Menurut Pola Hidup}

Tabel 5. Distribusi Penduduk Menurut Pola Hidup

\begin{tabular}{lcccc}
\hline \multicolumn{1}{c}{ Pola Hidup } & \multicolumn{2}{c}{ Dataran Tinggi } & \multicolumn{2}{c}{ Dataran Rendah } \\
& $\mathrm{n}$ & $\%$ & $\mathrm{n}$ & $\%$ \\
\hline Makanan bergaram & 25 & 31,2 & 34 & 42,5 \\
Alkohol & 11 & 13,7 & 32 & 40 \\
Konsumsi Daging & 6 & 7,5 & 17 & 21,2 \\
Merokok & 12 & 15 & 30 & 37,5 \\
Tidak pernah olahraga & 29 & 36,2 & 51 & 63,7 \\
& & & & \\
\hline
\end{tabular}

Berdasarkan tabel 5, penduduk yang tinggal di dataran rendah lebih banyak mengkonsumsi garam berlebih sebanyak 34 orang (42,5\%) dibandingkan di dataran tinggi sebanyak 25 orang (31,2\%). Hasil penelitian ini sejalan dengan penelitian hubungan asupan zaz gizi dengan kejadian hipertensi di Pulau Manado Tua yang dilakukan oleh Setiawati. ${ }^{10}$ menunjukkan bahwa terdapat hubungan yang signifikan antara natrium dengan kejadian hipertensi. Asupan natrium yang meningkat menyebabkan retensi cairan sehingga tekanan darah naik. $^{13}$

Penduduk yang tinggal di dataran rendah lebih banyak mengkonsumsi alkohol sebanyak 32 orang (40\%) dibandingkan di dataran tinggi sebanyak 11 orang (13,7\%). Konsumsi alkohol berlebihan dapat berdampak buruk pada organ tubuh seperti jantung dan hati, selain 
itu dapat menyebabkan kerusakan pada pembuluh darah yang berakibat pada kenaikan tekanan darah.

Penduduk yang tinggal di dataran rendah lebih banyak mengkonsumsi daging sebanyak 17 orang (21,2\%) dibandingkan di dataran tinggi sebanyak 6 orang (7,5\%). Konsumsi daging yang berlebihan dapat menyebakan kenaikan kolesterol. LDL merupakan kolesterol jahat yang dapat menyebakan penyumbatan arteri yang memicu terjadinya hipertensi. ${ }^{7}$

Penduduk yang tinggal di dataran rendah lebih banyak merokok 30 orang $(37,5 \%)$ dibandingkan di dataran tinggi sebanyak 12 orang (15\%). Nikotin dan karbon monoksida (CO) yang tekandung di dalam rokok dapat merusak dinding pembuluh endotel (dinding pembuluh darah) sehingga dapat menyebabkan peningkatan tekanan darah. ${ }^{7}$

Penduduk yang tinggal di dataran rendah lebih banyak tidak berolahraga sebanyak 51 orang (63,7\%) dibandingkan di dataran tinggi sebanyak 29 orang (36,2\%). Penelitian yang dilakukan oleh Aris S, bahwa orang yang tidak biasa berolahraga memiliki risiko terkena hipertensi sebesar 4,73 kali dibandingkan orang yang memiliki kebiasaan olahraga. ${ }^{14}$

Tabel 6. Distribusi Penduduk Menurut Klasifikasi Tekanan Darah Sistole (WHO)

\begin{tabular}{lcccc}
\hline \multirow{2}{*}{ Tekanan Darah Sistole } & \multicolumn{2}{c}{ Dataran Tinggi } & \multicolumn{2}{c}{ Dataran Rendah } \\
& $\mathrm{n}$ & $\%$ & $\mathrm{n}$ & $\%$ \\
\hline Optimal & 20 & 25 & 11 & 13,75 \\
Normal & 24 & 30 & 9 & 11,25 \\
Normal Tinggi & 16 & 20 & 24 & 30 \\
& & & & \\
\hline & 15 & 18,75 & 26 & 32,5 \\
\hline Hipertensi Ringan & 2 & 2,5 & 5 & 6,25 \\
Hipertensi Sedang & 3 & 3,75 & 5 & 6,25 \\
Hipertensi Berat & & & & \\
& & 25 & & 45 \\
\hline & 80 & 100 & 80 & 100 \\
\hline Total & & & & \\
\hline
\end{tabular}

Tekanan darah normal sistole $75 \%$ lebih banyak di dataran tinggi dibandingkan dengan dataran rendah 55\%. Sedangkan tekanan darah sistole pada hipertensi lebih banyak di dataran rendah $45 \%$ dibandingkan dengan dataran tinggi $25 \%$.

\section{Distribusi Penduduk Menurut Klasifikasi Tekanan Darah (WHO)}

Tabel 7. Distribusi Penduduk Menurut Klasifikasi Tekanan Darah Diastole (WHO)

\begin{tabular}{lcccc}
\hline \multirow{2}{*}{ Tekanan Darah Diastole } & \multicolumn{2}{c}{ Dataran Tinggi } & \multicolumn{2}{c}{ Dataran Rendah } \\
& $\mathrm{n}$ & $\%$ & $\mathrm{n}$ & $\%$ \\
\hline Optimal & 26 & 32,5 & 7 & 8,75 \\
Normal & 31 & 38,75 & 20 & 25 \\
Normal Tinggi & 1 & 1,25 & 2 & 2,5 \\
& & & & \\
\hline
\end{tabular}




\begin{tabular}{lcccc}
\hline & \multicolumn{3}{c}{72,5} & 36,25 \\
\hline Hipertensi Ringan & 13 & 16,25 & 33 & 41,25 \\
Hipertensi Sedang & 8 & 10 & 12 & 15 \\
Hipertensi Berat & 1 & 1,25 & 6 & 7,5 \\
& & & & \\
\hline Total & & 27,5 & & 63,75 \\
\hline
\end{tabular}

Tekanan darah normal diastole 72,5\% lebih banyak di dataran tinggi dibandingkan dengan dataran rendah 36,25\%. Sedangkan tekanan darah diastole pada hipertensi 63,75\% di dataran rendah lebih banyak dibandingkan dengan dataran tinggi 27,5\%.

\section{Klasifikasi Tekanan Darah (WHO)}

Berdasarkan klasifikasi tekanan darah WHO, data penduduk yang ikut serta dalam penelitian ini di uji menggunakan uji statistik Chi-Square. Selanjutnya, data di distribusikan dalam bentuk tabel dan menunjukkan hasil bahwa tekanan darah sistole $\mathrm{p}=0.008$ dan tekanan darah diastole $\mathrm{p}=0.000$. Hasil penelitian tersebut menunjukkan bahwa terdapat perbandingan yang signifikan antara tekanan darah baik sistole maupun diastole di dataran tinggi dan dataran rendah yaitu jumlah penduduk dengan hipertensi lebih tinggi di dataran rendah dibandingkan di dataran tinggi.

\section{Perbandingan Hasil Tekanan Darah Antara Dataran Tinggi dan Dataran Rendah}

Uji statistik yang digunakan adalah non parametrik yaitu uji Mann Whitney U untuk membandingkan data yang tidak terdistribusi secara normal dan tidak berpasangan didapatkan hasil tekanan darah baik sistole maupun diastole antara penduduk yang tinggal di dataran tinggi (Kelurahan Rurukan) maupun yang tinggal di dataran rendah (Kelurahan Malalayang).

Dari hasil analisis, dapat di lihat nilai asymp. Sig (2-tailed) sebesar $\alpha=0.000$ lihat. Secara statistik angka-angka ini menunjukkan bahwa ada perbandingan yang signifikan antara kedua variabel tersebut, yaitu hipertensi di dataran rendah lebih tinggi dari pada di dataran tinggi.

\section{SIMPULAN}

Terdapat perbedaan yang signifikan $\alpha<0.005$ pada hasil pengukuran tekanan darah antara penduduk yang tinggal di dataran tinggi dan dataran rendah. Sehingga H1 diterima dan HO ditolak.

\section{SARAN}

Perlu dilanjutkan penelitian dengan sampel yang lebih banyak pada wilayah lain yang memiliki karakteristik daerah yang sama dengan penelitian ini dan perlu dilakukan penelitian yang lebih lanjut dengan memasukan variabel-variabel yang dapat mempengaruhi tekanan darah itu sendiri misalnya obesitas. 


\section{UCAPAN TERIMA KASIH}

Dalam penyusunan karya tulis ini penulis mendapat banyak bantuan baik moril maupun materil dari berbagai pihak. Untuk itu, dengan penuh kerendahan hati dan rasa hormat, penulis hendak menyampaikan terima kasih kepada kepada dr. Sylvia Marunduh, M.Med., AIFM., AIFO dan dr. J. J. V Rampengan, AIFM., AIFO selaku Dosen Pembimbing I dan II. Berterima kasih juga kepada dr. Herlina. I.S. Wungouw, MsAppSc., MMedEd., AIFM., AIFO dan dr. D. H. C Pangemanan, M.Kes., AIFM., AIFO selaku dosen penguji I dan II. Penulis juga menyampaikan banyak terima kasih kepada dr. Joice. Nancy. A. Engka, MKes., AIFM., AIFO.

\section{DAFTAR PUSTAKA}

1. Watson R. Anatomi Fisiologi untuk Perawat . Ed 10. Jakarta: EGC:p.261-6.

2. Guyton AC. Fisiologi Manusia dan Mekanisme Penyakit. Jakarta: EGC,1992:p.128.

3. Sherwood L. Fisiologi Manusia dari Sel ke Sistem. Ed 2. Jakarta: EGC,1996:p.297:341.

4. WHO. Global Health Observasy (GHO) raised blood pressure [homepage internet]. [cited 2013 Sept 10]. Availabe From:http://www.who.int/gho/ncd/risk_factors/blood_pressure_prevalence_text/en/.

5 WHO. NCD country profile [homepage internet]. 2011. [cited 2013 Sept10].Available from: http://www.who.int/nmh/publications/countries/idn_en pdf.

6. Departemen Kesehatan RI. Laporan Hasil Riset Kesehatan Dasar 2007. Jakarta: Badan Penelitian dan Pengembangan Kesehatan Departemen Kesehatan Repulik Indonesia;2007.

7. Gardner FS. Smart Treatment For High Blood Pressure. Jakarta, 2007.

8. Alice HL, Lawrence JA, Michael B, et al. Summary of American Heart Association Diet and Lifestyle Recommendations Revision 2006. Arteriosclerosis, Trombosis, and Vascular Biology. 2006; 26: 2186-2195.

9. Bustan M. Epidemiologi Penyakit Tidak Menular. Jakarta: Rineka Cipta, 2007.

10. Setiawati S. Hubungan Asupan Zat Gizi Dengan Kejadian Hipertensi di Pulau Manado Tua Kecamatan Bunaken Kota Manado. Manado, 2006.

11. Chalmers J et al. WHO-ISH Hypertension Guidelines Committee. 1999 World Health Organization - International Society of Hypertension Guidelines for the Management of Hypertension. J Hypertens, 1999;17:151-185.

12. Sundari, Aulani’am, Djoko Wahono S, M Aris Widodo. Faktor Risiko Non Genetik dan Polimorfisme Promoter Region Gen CYP11B2 Varian T(-344) Aldosterone Synthase pada Pasien Hipertensi Esensial di Wilayah Pantai dan Pegunungan. 2013.

13. Guyton and Hall. Buku Ajar Fisiologi Kedokteran. Ed 11. Jakarta: EGC, 2006:p.230-1.

14. Sugiharto A. Faltor-faktor Risiko Hipertensi Grade II pada Masyarakat (Studi Kasus di Kabupated Karanganyar). [internet homepage]. 2007. [cited 2014 Feb 11]. Available from: : http://eprints.undip.ac.id/16523/1/Aris_Sugiharto.pdf.

15. Mansjoer A, dkk. Kapita Selekta Kedokteran Jilid I. Jakarta: Media Aesculapius FKUI, 2001; 520. 